\title{
The Battle of Truths: The Production of Meaning in Indonesian Political Memes
}

\author{
Agustinus Dias Suparto \\ Graduate Program \\ Faculty of Letters \\ Petra Christian University \\ agustinusdiassuparto@gmail.com
}

\begin{abstract}
Memes have been used in the public discussion nowadays by the internet users and the emergence of social media especially Instagram has facilitates people to share their opinions. Thus, people are trying to influence each other using memes about the political tension which involves Basuki Tjahaja Purnama about his blasphemy case on Islamic verse in Al Quran and Habib Rizieq's case. Therefore, in order to influence other using memes, several iconic figures are used to produce the meaning about the truths that are said by those figures in each faction. The using of news as the valid data to represent the reality is also used to be the truth that should be believed by the readers of the memes. Later, this paper will try to analyze using discursive approach on how memes use several features to convince the readers to believe that the meaning in the memes is the truth. Finally the memes from two political factions which are pro and cons about the cases are used to reveal the meaning production in memes.

Keywords: meaning, production, truths, meme
\end{abstract}

\section{INTRODUCTION}

The development of information technology especially internet has influenced the society on their communication. Thus, many people have more access of the information from all over the world through internet which spreads very quickly. This kind of situation implies on their broaden knowledge of other cultures and societies and there are discussion about the societal issues among the societies. Later, memes emerge as the product of society to share their opinions in the public discussions in the internet. Memes, in one point is the way to promote cultures and societal issues among people who use the internet and to trigger public discussions and participations.

In Indonesian context, the issue which has been popular among Indonesian people is the discourse of Basuki Tjahaja Purnama's case during Jakarta governor election and Habib Rizieq's case on his pornographic chat. People have been divided into two big factions who are supporting the incumbent candidate, Basuki Tjahaja Purnama or "Ahok" and against his candidacy. Moreover, the case of whether Ahok blasphemed one of the verses in Al Quran when he was explaining his program for the fishermen in Kepulauan Seribu, Northern Jakarta has added the controversy to the peak. The implication of his speech was massive for those who are against it. The series of demonstrations, led by Rizieq Shihab, demanding his imprisonment has proven to be effective for putting the incumbent's electability down in the first round of the election although he was still leading by earning around $42 \%$ of the votes. The two factions of people now have the duel in the second round of the election as the candidates who compete are only two. Thus, it affects the supporters of each candidate to launch all effort that they can do by more intensively influencing the public opinion through social media, especially memes.

However, the political factions in the election continue as there are two groups who oppose each other. Every political phenomenon is seen using two perspectives of these two factions. Moreover, when there was leaked pornographic chat which involves Habib Rizieq and Firza Husein. In the chat, there is conversation in which Habib Rizieq tries to persuade Firza Husein to show her naked photos and later there is also conversation in which Habib Rizieq begs Firza Husein not to talk about their sexual relationship to his wife. This case has been controversy since then as the supporters of Habib Rizieq see this case as criminalization and character assassination whereas those who do 
not like Habib Rizieq see this case as uncommon pornographic case because it is done by a cleric which has thousands of followers.

Therefore, this phenomenon of the factions of people in the election is actually ideological. They have their ideas about the criteria of being the leader. For Ahok's supporters, Ahok's achievements during his time as the Jakarta governor have convinced them that Ahok is the best candidate. On the other hand, they think that Ahok is not suitable to be the governor because of several factors, some of which are his religion, ethnicity and leadership style. Later, the debates continue when there is pornographic chat involving Habib Rizieq as the leader of Islam Defender Front (FPI) with Firza Husein, a widow that is close to his wife. There are debates and arguments on whether Ahok is the best candidate and whether Habib Rizieq is guilty in his case in social media, especially in Instagram where it enables the user to share the pictures. Thus, the using of memes can be the way to promote their idea in the debate of the best candidate in the election and about Habib Rizieq's case.

The memes presented can be critical or satirical which attack the candidates and the people who support them. Although meme consists of picture and some words, there is also caption which contains the comment of the person who posts the meme in the social media. The meme and its caption are the way to convey their support or opposition of the governor candidate and their supporters. The term of "meme" was coined first by Richard Dawkins, a zoologist, in his book titled "The Selfish Gene" which talks on how genes multiply information. Meme is used as it transfer the cultural information which similar to gene which transfer the biological information. Thus, according to Dawkins, "memes" include, inter alia, music, fashion, ideas, common phrases, official and common types of behaviour, rituals, and religious beliefs (Gorka, 2014, p.226). Similar to that idea, the use of memes in the internet has influenced people about seeing a particular thing which happens in a certain place in the world. It can be in satirical or humorous way which brings sense of idea of certain group of people about a particular topic. Thus, the using of meme can influence people on how people see a certain issue in the world.

Chandler (2013) added that imitation is the key to Dawkins' notion of the meme because imitation is the means by which memes propagate themselves amongst members of a culture (p.8). Internet memes can appear on the internet blogs, social networking sites and emails in the form of pictures, sounds, and films as it has several forms which can spread rapidly or "virally" to the internet users. Some of memes are critical, satirical, humorous, emotional and sometimes controversial which brings attractiveness to the readers to join in the public discussions. Thus, by joining in public discussion in memes, more people are engaged emotionally to see the perception of the meme-maker toward a certain event.

Stuart Hall (1997) has argued meaning production as one of the components of circuit of culture which is portrayed by Paul du Guy (19..). He argued that representation cannot be separated with the meaning which it is represented and the language as the medium to share the meaning. He also added how representation, meaning and language work as unity to create meaning in a culture:

"Members of the culture must share sets of concepts, images and ideas which enable them to think and feel about the world, and thus to interpret the world, in roughly similar ways. They must share, broadly speaking, the same 'cultural codes'. In this sense, thinking and feeling themselves 'systems of representation', in which our concepts, images and emotions 'stand for' or represent, in our mental life, things which are or may be 'out there' in the world. Similarly, in order to communicate the meanings to other people, the participants to any meaningful exchange must also be able to use the same linguistic codes - they must, in a very broad sense, 'speak the same language'“.(Hall, 1997, p.2)

Thus, in the memes as the cultural products also represent how the society sees certain images, concepts and ideas. That representation of the images, concepts and ideas also creates meaning which is shared within the society. The meanings that are implied are often can be categorized as good or bad depending on the society. Some belief are regarded as truth by a certain group of people that should be followed by the member of that society. Memes, as a cultural product also represent about what is good or bad in the society which sometimes can be used as jokes or sarcasm to attack particular group of people who do not have the similar value. Therefore, memes 
are the cultural products which can represent certain concepts and ideas which are believed as truths in a certain society.

Truth is one of the power relation theories that are popularized by Michel Foucault (1976) who has claimed that "truth isn't outside power, or deprived of power" (p.113). On the contrary, he argues that truth "is produced by virtue of multiple constraints and it induces regulated effects of power". This is to say that "each society has its regime of truth", and by this expression, Foucault means that "the types of discourse or the society harbors and causes to function as true". He later also added that truth is the result of "the mechanisms and instances which enable one to distinguish true from false statements" and "the way in which each is sanctioned". It is also related to "the techniques and procedures which are valorized for obtaining truth" and "the status of those who are charged with saying what counts as true" (Foucault, 1976, p. 112; 13).

Therefore, "truth" is "a system of ordered procedures for the production, regulation, distribution, circulation and functioning of statements"; it is linked "by a circular relation to systems of power which produce it and sustain it, and to effects of power which it induces and which redirect it". And right at the end of the interview, Foucault adds that the essential political problem for us, today, is trying to change our "political, economic, institutional regime of the production of truth" (where truth is modeled on the form of scientific discourse), in order to constitute a new "politics of truth (Foucault, 1976, pp. 113-114). Therefore, this paper will try to reveal how truth is created to influence people using certain images, concepts and ideas in memes.

The data will be taken from the memes which are spread in Instagram by several accounts which support Ahok and oppose him. The accounts which support Ahok which are selected are @front_pembela_akal_sehat,@memefilkada and. On the other side, the accounts which oppose Ahok or support Anies are @ dpp_fpi and @warkop_id. The data will be specifically chosen from these accounts which talk about the issue of Jakarta governor election using discursive approach and comparative method. Finally, this paper will discuss how people use memes to produce meaning to promote their "truth" of who they should vote in the second round of the election and whether Habib Rizieq is guilty for the pornographic chat.

\section{Production of Meanings on the truths in Al Maidah Verse 51 case}

As Michael Foucault said that "each society has its regime of truth", it can be concluded that the factions of people who support and oppose Ahok have their own "truth" which are produced though cultural products like memes (Foucault, 1976, p.112). Thus, memes are used to convey what they think as their "truth" to the society in social media, which in this context, Instagram is used. The factions are divided because they have different perspective of what is going on in the society. One has claimed that rationality has become the main thing that a person who has done many achievements should be supported like the incumbent, Ahok. On the other hand, they who do not like Ahok think that Ahok is not good for them because of his blasphemy speech in Kepulauan Seribu which disgraces their belief about who should be the leader of Muslim people. However, the discourse of who should be the leader of Muslim people in the context of Jakarta governor is controversial. Thus, memes are used to convey the meaning of their idea and concepts related to the election. Both sides claim that they are Muslim and they have their own interpretation, especially related to what the verse 51 of Al Maidah in Al Quran which says about Muslim people should vote for Muslim leader like in the meme from@dpp_fpi. Here is the memes related to the election which are produced and shared by that account which represent the truth that they believe using pictures and languages as the way to convey their meaning to influence the audience. 


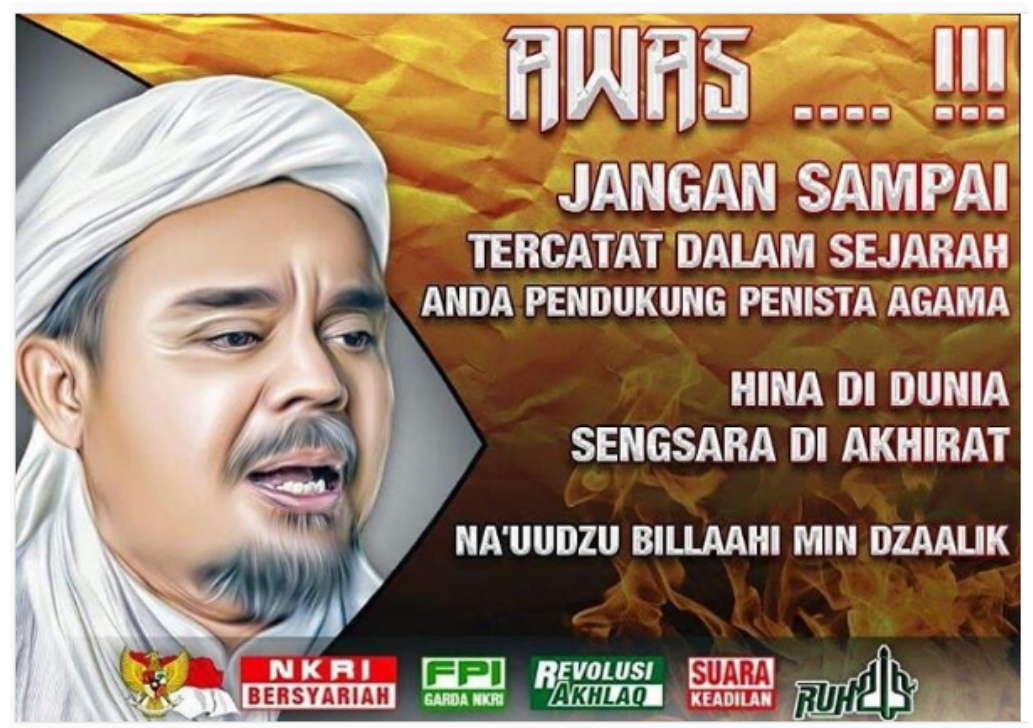

Beware!!! Don't be ever historically recorded as the supporters of the blasphemer. Being vile in the world, suffering in the hereafter

From the FPI or Islam Defender Front, the group of people who are vocal opposing Ahok's candidacy, believe that Ahok is the blasphemer of their belief related to vote Muslim leader. As the court is still going on, they insist that Ahok is guilty for the blasphemy of Muslim, so Muslim people should not support him because he is considered as kafir or pagan. Moreover, they attack the Muslim people who support Ahok with their belief that the supporter of the pagan candidate will get Allah's anger.

Moreover, as Foucault (1976) says that truth also depends on "the techniques and procedures which are valorized for obtaining truth" and "the status of those who are charged with saying what counts as true", they believe such interpretation because the interpreter of the verse 51 in Al Maidah is Habib Rizieq Shihab who they think that he is the person who has power and knowledge in Islam (p. 112; 13). The fact that he has title as "Habib" gives him power to influence many people as "Habib" can only be gained if they have the lineage of the main prophet of Islam, Muhammad and have broad knowledge in Islam. Thus, by using his picture in the meme, it is explicitly implied that those words in the memes are what Habib Rizieq said which should be obeyed by Muslim people because of his expertise in interpreting Al Quran. Thus the use of picture of Habib Rizieq Shihab as the icon of the certain Muslim group who is also the respected person or Ulama among Muslim people in the meme represent that the words in the memes are his words which should be believed by the people.

On the other hand, Muslim people who think that Ahok is not guilty, they have their own interpretation of what the truth is related to Ahok's blasphemy case. They think that the interpretation is just for their political sake in which they support for the other candidate. Thus, to "counter" the "truth" of the FPI followers, they use several famous Indonesian ulama or Muslim scholars, such as Gus Dur, who is also the third president of Indonesia and the former leader of the biggest Islamic group in Indonesia, Nahdatul Ulama as the representation of moderate Muslims which is more nationalist. Here, @memefilkada uses Gus Dur as the representation of Ulama who has good reputation on his knowledge of Islam and what he says in the meme is used as the representation of the truth of the interpretation of Al Maidah verse 51. 


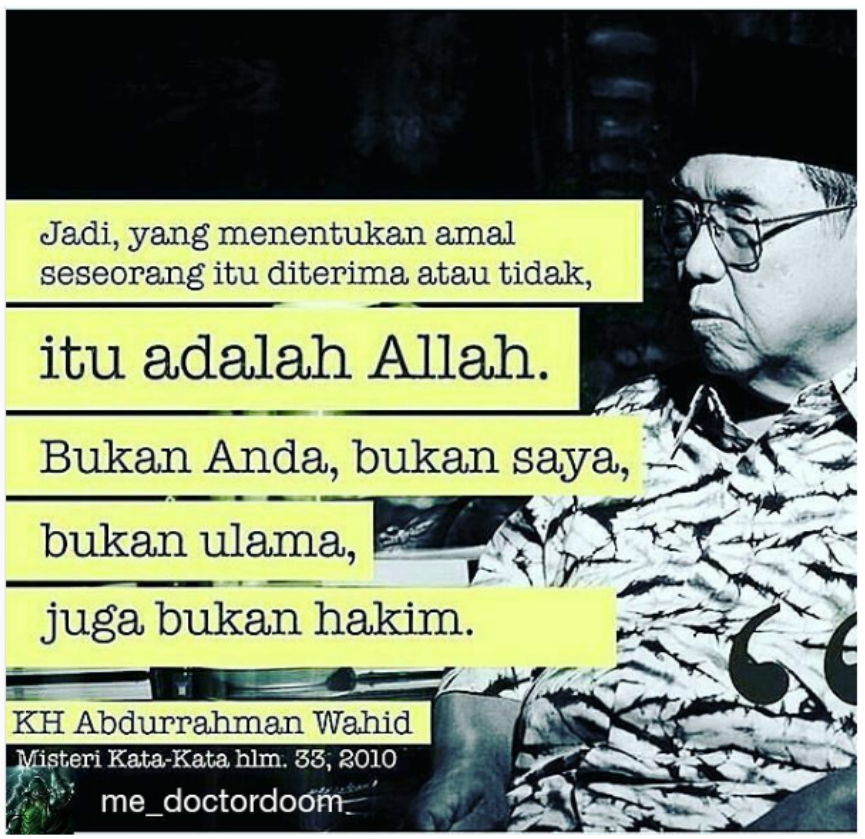

So, the one who decides one's good deed is accepted or not is God.

Not you, not me, not ulama (Muslim scholars) and not judge

From this point of view, they do not believe in what Habib Rizieq has interpreted on the $51^{\text {st }}$ verse of Al Maidah by believing the ideology of unity in diversity which is once promoted by $\mathrm{KH}$ Abdurrahman Wahud or Gusdur. The title of "KH" or "Kyai Haji" means that he is a respected and wise person in the society and he has become the icon of Ulama which values on multiculturalism as Indonesia has diversity in religions. Therefore, these people do not believe Habib Rizieq's interpretation because they think what Gusdur taught them is more correct, especially about tolerance among Indonesian people and the concept of Bhineka Tunggal Ika or Unity in Diversity. Moreover, his position as the former leader of Nahdatul Ulama which is the biggest Muslim organization in Indonesia still has the effect on how people see Ahok's case. Therefore, by using the photo of Gusdur, the meme implies that the "truth" that the followers of Habib Rizieq believe in is not correct because it is not what Gusdur has taught the people about Islam.

Finally, there are two kinds of "truth" of Muslim people in Indonesia, which see the different things about the implication of voting Ahok for the election. On the one hand, there is "truth" that Muslim people will get God's anger if they choose a pagan person for their leader. However, the other Muslim group believes that God won't be angry at them because of voting Ahok as the governor because they think Ahok is the best candidate in the election although he is not Muslim. Therefore, meme is used to promote their "truth" related to whether Ahok should be voted or not because there are different interpretations of the $51^{\text {st }}$ verse in Al Maidah. To produce the convincing meaning production in memes, Habib Rizieq and Gus Dur are used as the representation of Ulama who should be obeyed by Muslim people in Indonesia. The using of Habib Rizieq and Gus Dur as the powerful figure in producing meaning about the interpretation of Al Maidah verse 51 in the political tension in the Jakarta governor election has also been more effective than the other figures in FPI or in NU as they are seen as the ones who have the best knowledge to convey the truths in the memes.

\section{Production of Meanings on the truths in Habib Rizieq's Case}

In information era, news has been crucial in producing information to the audience worldwide. White (2006) has claimed that news reporting, especially, as ideologically inclined and with an agenda to influence its intended audience (p.1). However, still many people unconsciously believe that news contains reality which causes many people are mislead by hoax news. Mineshima (2009) has found that even when the writing is not too biased, the reader may not be aware to accept some writer's perspectives about a fact. Thus, news is still seen as the representation of the reality because many people have not realized that news is used to direct the audiences to a certain 
perspective that the writer wants. Thus, news can be used as to produce meaning to convince the reader about what really happens in the society. Here, news are used as the representation of the truth that the writer wants the audience to believe like in the meme below from @ dpp_fpi as the supporter of Habib Rizieq.

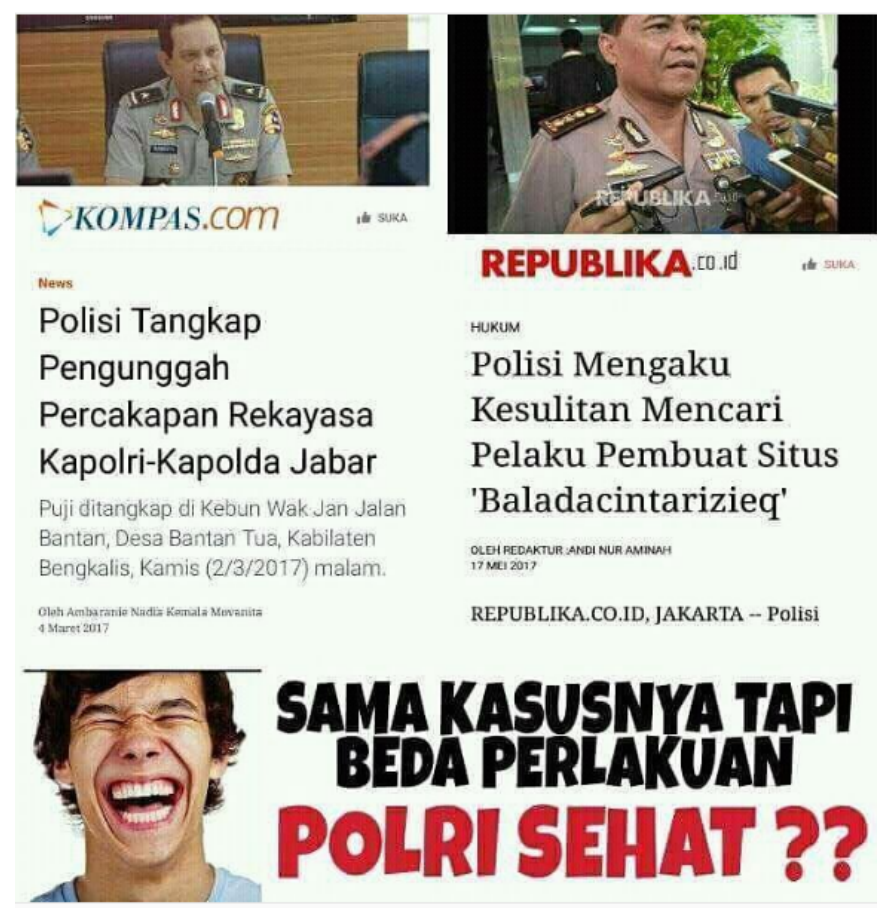

News from Kompas.com: The Police Caught the Creator of the Chat between Indonesian Police Leader and West Java Police Leader.

News from Republika.co.id: The Police admit difficulties on Seeking the Host of "Baladacintarizieq" Caption: The cases are the same, but (they have) different treatment. The Police, (are you) okay??

Here, the meme uses news comparison between two cases which are about the chat of the leader of Indonesian Police that ordered to criminalize Habib Rizieq and about the pornographic chat which involves Habib Rizieq. Then, there is caption saying that those two cases are similar but treated differently and then it questions the police's credibility. The fisrt case about the chat involving the leader of Indonesian police is proven as hoax, but the second case which is about the pornographic chatting involving Habib Rizieq is not proven yet in the court. However, they think that the case of Habib Rizieq is also manipulated by people who do not like their leader, thus the police should seek for the people who viralize the unproven chat between Habib Rizieq and Firza Husein. Therefore, because the police insist to pursue Habib Rizieq, they think that the police is being unfair and see this case as criminalization toward their leader. They claim that the case of Habib Rizieq is just an attempt to discredit their leader because they think that the one that should be pursued it the person who created the pornographic chat and viralized it on the website called "baladacintarizieq". In this case, meme which are uploaded by @dpp-fpi as the supporter of Habib Rizieq implies that the case of their leader is manipulated by the police because they do not believe that the chat which involves Habib Rizieq and Firza Husein is true. Thus, by comparing those two news, they want to convince the audience that the police is not fair toward them, especially their leader, Habib Rizieq.

People will believe more in the authorized newspaper because it has "cultural codes" that are shared in the society as the credibel source of reporting the reality (Hall, 1997, p.2). Thus, @ dpp_fpi tries to convince netizen that the police is criminalizing Habib Rizieq by using the screen shot of online newspaper that are quite popular in Indonesia which are Kompas.com and Republika.co.id. Then, by comparing the two cases between the chat of the Indonesian Police leader and Habib Rizieq, the author wants to convince people that those two cases are similar and both are manipulated. Then the caption below showing a picture of laughing man represents the feeling of the maker of the meme that the police's credibility is questionable because the police investigate the two cases differently. Thus, the meme is used to convice people that they should believe that Habib 
Rizieq is just the victim of his pronographic chat case and should not believe in the police. Therefore, news can be used in meme as the representation of the truth of what really happens in the society because news are seen as more credible source of reality.

On the opposite, news is also used by the people who believe that Habib Rizieq is guilty for the content of his chat with Firza Husein. The account @ front_pembela_akal_sehat also made a meme using a screen shot of online newspaper to convince the netizen that Habib Rizieq should be punished for his pornographic chat like in the meme below.

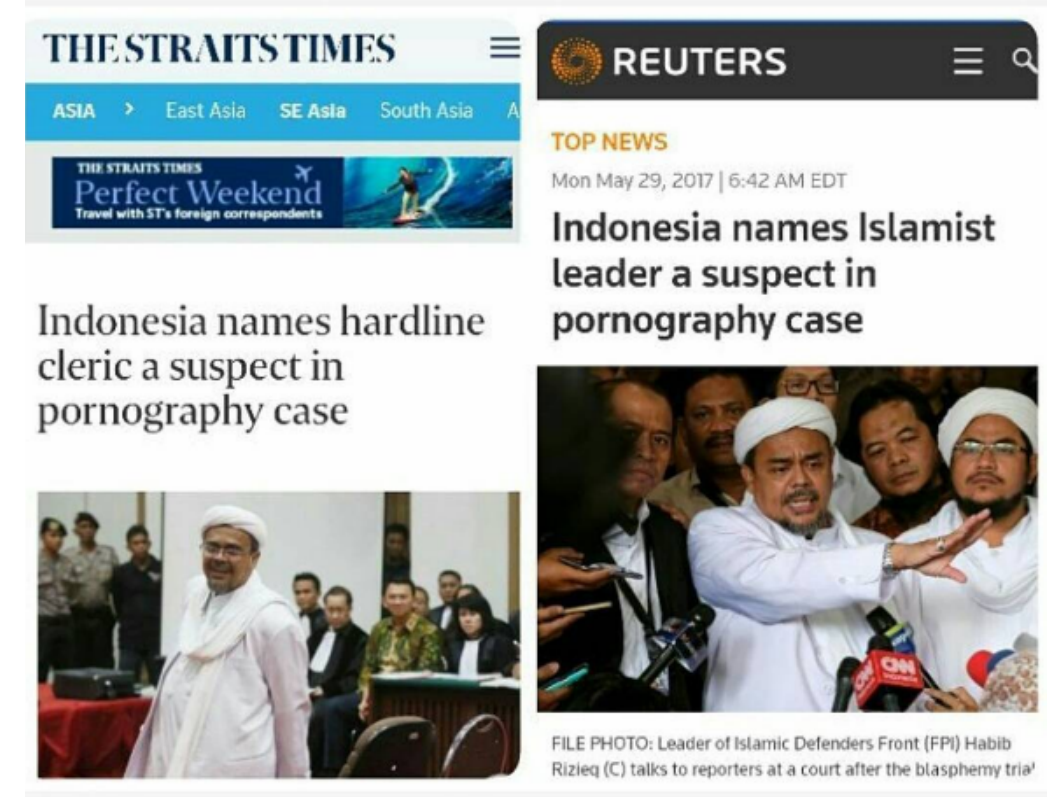

Slightly different than the previous meme that there is no comment of the author's thinking related to the content of the news, it is clearly stated that @ front_pembela_akal_sehat wants to show the people that Habib Rizieq is guilty and should support the authority to imprison Habib Rizieq because it has been clearly shown in the online newspaper that Habib Rizieq is a suspect for his case. However, the main objective of putting news into this meme is to discredit Habib Rizieq as the leader of Islamic Organization and as respected ulama by many people, especially FPI (Islamic Defender Front) members. By showing that he is involved in pornographic case, the author wants to question Habib Rizieq's credibility as the one who should be the example for many people because of his reputation as an Islamic cleric who has many followers in Indonesia. Therefore, it is implied that the author of the meme wants to show the truth that Habib Rizieq is not a representation of good ulama because he cannot be the good example for Muslim people.

Moreover, the using of abroad online newspaper which are from The Strait Times and Reuters shows that people abroad see Habib Rizieq as criminal who has pornographic case. The using of abroad online newspaper also implies the credibility that the memes want to imply as those online newspapers such as Reuters and The Strait Times are also iconic which have good reputation among the people worldwide. Those iconic online newspapers also create more sense of credibility in providing the truth to make the readers believe of what really happens. Thus, it also implies that Indonesian people who still idolize Habib Rizieq as ulama to open their eyes about what happens to Habib Rizieq not as a trustworthy person as he is involved in pornographic case with a widow.

\section{CONCLUSION}

Political memes which are used to influence people must have something that can make people believe of the content of the memes. Thus, several features that can represent the "truth" that society believe can be the way to convince the audience about the political events that happens in society. In the case of Ahok and Habib Rizieq, there are two kinds of truth that the society should believe, whether they are guilty or not. Thus, a person who is respected because of his expertise in Islam can be the representation of the true interpretation of Al Maidah verse 51 in Ahok's case such 
as Habib Rizieq and Gus Dur. Because they have different view on Ahok's case, the truth then seems to be competed in the society. Those "truths" are used to what Foucault (1980) said to "expose the individual to maximum visibility, which brings up a new form of internalized disciplinary practice: the person is forced to behave as if someone is permanently watching, even if this is not necessarily the case" (p.167). Thus, by using believing the "truth" based on the interpretation of the $51^{\text {st }}$ verse in Al Maidah, people will discipline themselves whether to vote Basuki Tjahja Purnama popularly known as Ahok or the other candidate, Anies Baswedan.

On the other hand, news can also be the representation of reality which produces more convincing data to influence the audience in memes. Although White (2006) has stated that news itself are influenced by the writer's perspective and agenda, the using of news as the source of data in the memes are also influenced by the author of the meme. Thus, the news picked in the meme is selected by the creator of the meme to shape a certain perspective to the audience. Foucault (1980) also stated that truth can be created as long as there is a system of ordered procedures for the production, regulation, distribution, circulation and functioning of statements (p.113). Thus, the using of credible newspaper as the source to convince the readers can be effective as they are seen as the mean to report the reality. Therefore, news screenshot in the meme can function as the representation of the truth that the author wants to imply and influence the readers as the truth that they should believe.

\section{REFERENCES}

Chandler, R. 2013. Meme World Syndrome: A Critical Discourse Analysis of the First World Problems and Third World Success Internet Memes. University of Central Florida: Florida

Gorka, M. 2014. The meme as an example of carnivalized internet communication. Kwartalnik Naukowy OAP UW"e-Politikon". Vol.9.pp.215-242

Foucault, M, 1977. Discipline and Punish: The Birth of the Prison, London: Allen Lane

Foucault, M, 1980. Power/Knowledge: Selected Interviews and Other Writings 1972-1977, London: Harvester Press

Foucault, M, 1980. Truth and power, in C. Gordon (ed.), Power/Knowledge, Brighton: Harvester Hall, S. 1997. Representation: Cultural representations and signifying practices. London: Sage in association with the Open University.

Mineshima, M. (2009). Discourse Analysis of News Texts by the Application of Systemic Functional Grammar. Niigata Institute of Technology. Pp. 101-123

White, P. R. R. (2006). Evaluative Semantic and Ideological Positioning in Journalistic DiscourseA New Framework for Analysis. In Larsen, I (ed.). Mediating Ideology in Text and Image: Ten Critical Studies. John Benjamins, Amsterdam. Pp. 37-69 